\title{
PROCESS SERVICES CONTRIBUTING TO IRON MAKING RESULTS IN FACE TO RECENT SCENARIOS*
}

\author{
André de Cabral Oliveira ${ }^{1}$ \\ Victor Oliveira ${ }^{2}$ \\ Mário Fernando Gomes de Almeida Cunha ${ }^{3}$ \\ Márcio Mendes Dumont Ferreira ${ }^{4}$
}

\begin{abstract}
With the onset of the global economic crisis in 2008, and more precisely from 2009 , production routes in iron making as blast furnace, sinter and coke oven, indicated a significant increase in frequency as well as intensity of undesirable incidents. The cost impact of such deteriorations of the production chain cause significant losses ranging up to several hundred million dollars annually. On the other hand, opportunities for processes improvement are contributing to enhance process efficiency and results, and also reduce or even avoid losses from unexpected incidents. The use of specialized services for processes has gained projection along the plants and emerged as an attractive alternative to increase results by increasing the performance and reducing costs and expenses. Process Services are formatted to achieve cooperative and customized solution during planned or urgent interventions, conducting feasibility studies, process improvement, training, among others, providing knowledge, information and crucial actions to preserve and optimize processes and plant facilities.
\end{abstract}

Keywords: Blast furnace; Sintering; Coke-making; Process services; Chilled hearth recovery; Process optimization.

1 Escola técnica federal do Espirito Santo, Analista de Sistemas, Analista de Processos Metalúrgicos, Vendas e Marketing, Paul Wurth do Brasil, Belo Horizonte, Minas Gerais, Brasil.

2 Universidade Federal de Minas Gerais Engenheiro Químico, Engenheiro Processos, Tecnologia, Paul Wurth do Brasil, Belo Horizonte, Minas Gerais, Brasil.

3 Universidade Federal de Minas Gerais, Engenheiro Metalurgista, Engenheiro de Vendas, Vendas e Marketing, Paul Wurth do Brasil, Belo Horizonte, Minas Gerais, Brasil.

4 Universidade Federal de Minas Gerais, Engenheiro Metalurgista, Engenheiro de Vendas, Vendas e Marketing, Paul Wurth do Brasil, Belo Horizonte, Minas Gerais, Brasil.

* Contribuição técnica ao 44 Seminário de Redução de Minério de Ferro e Matérias-primas, $15^{\circ}$ Simpósio Brasileiro de Minério de Ferro e 2o Simpósio Brasileiro de Aglomeração de Minério de Ferro, 15 a 18 de setembro de 2014, Belo Horizonte, MG, Brasil. 


\section{INTRODUCTION}

The actual global economic situation represents unfavorable conditions for the steel industry. For steel producers the crisis continues and there is a latent uncertainty about when the recovery will begin. This has the side-effect of many plants being forced to operate at production levels below normal operation.

As a result many steel plants face this as a considerable impact in form of lower production demand, lower margins, shrinking investment and increased costs. In addition many companies face an escalating deterioration of raw material quality and dispersal or migration of skilled labor to other areas.

Companies have to balance these negative impacts and make adjustments in their resources to remain cost effective. This may penalize the operation, maintenance and processes with a consequent reduction in stability and performance. Often these negative conditions go along with a decrease of equipment life time as a result of unstable operation conditions. For the medium and long term view such accelerated deterioration of equipment may cause huge losses as campaign life time decreases. Plants seeking to overcome above mentioned difficulties are working hard to better adjust their processes internally and to concentrate on continuous improvements, which are important factors in the preservation of plant facilities in face of unfavorable conditions and uncertain scenarios. These searches for solutions meet a complex equation: Efficiency increase and cost reduction while at the same time dealing with lowered maintenances and unavailability of resources.

Alternatives adopted by steel plants have been internal solutions for maintenance and partially effective actions in their processes. In practice these solution shows partial or inefficient results as shown by the monitoring conducted by companies providing specialized services for process, indicating a increasing in the number of incidents with direct impact on production. Monitoring data held by Paul Wurth S.A. shows a sharp increasing in the number of incidents in iron making process.

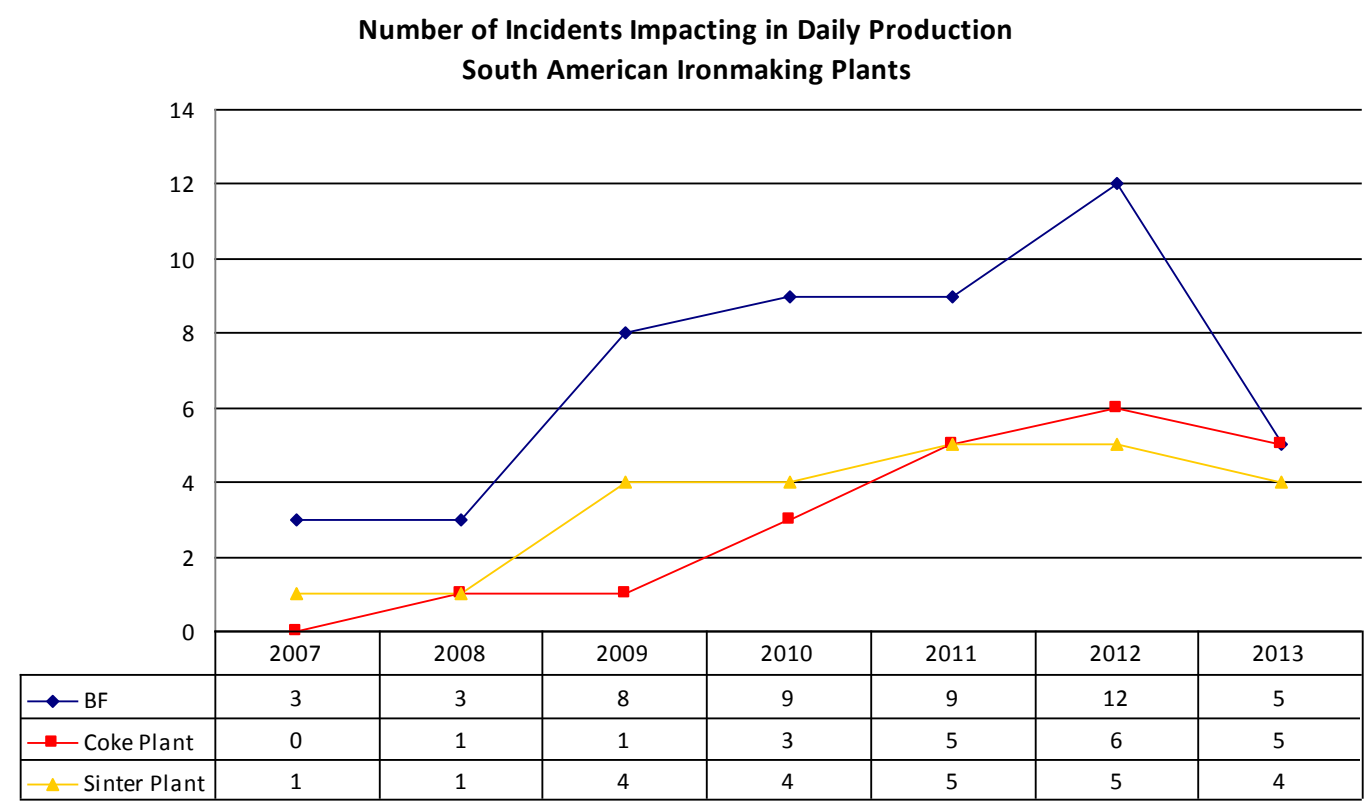

Figure 1 - Incidents per year with production impact.

* Contribuição técnica ao $44^{\circ}$ Seminário de Redução de Minério de Ferro e Matérias-primas, 15o Simpósio Brasileiro de Minério de Ferro e 2o Simpósio Brasileiro de Aglomeração de Minério de Ferro, 15 a 18 de setembro de 2014, Belo Horizonte, MG, Brasil. 


\section{PROCESS SERVICES}

As a result of above mentioned incidents an increased demand in process services can be noted over the last five years. Moreover it can be said that process services have become an important and integral part of plant operation. The reasons are manifold but can be understood by an examination of the actual situation in the plants in comparison to the advantages gained by process services supplied by external companies.

Optimization studies demand a considerable amount of calculation tools and process models which are costly to develop. Such models as well as experts for the different areas of blast furnace expertise are only available in few plants.

External process services provide companies with the possibility to concentrate on their core competencies and mitigate shortage of recourses.

Some of the severe problems that may deteriorate the processes in an iron-making plant are very rare. It can even be that the workforce has not faced such situations at all during the time before the crisis. Yet the development shows that such risks become currently more likely. This situation gets more pronounced as crisis forced many companies to reduce their staff. This led to a situation where often no local experts who have experienced certain phenomena are available and no new operators are trained because of the rare occurrence of such phenomena.

Use of external process services can offer greater budget flexibility and control. This lets companies pay for only the services they need, when they need them. It also reduces the need to hire and train specialized staff, brings in fresh engineering expertise, and reduces capital and operating expenses.

The reason for this is that for companies specialized in supply of dedicated process services such as Paul Wurth, not the same limitations apply in terms of frequency of such process services.

From supply of key components to the iron-making industry and its position as leading engineering company for the design of blast furnace plants, Paul Wurth employees a dedicated team of process experts backed-up by contacts to most experienced operators around the world.

The tools and routines created for determine an optimal design of blast furnace plant, sintering and coke-making can be used to assess their operation and to spot bottlenecks and areas for optimization.

The same applies for the process models supplied under the name BFXpert.

Dedicated models supplied to our customers as process control system, provide functionalities for cast house operation, charging optimization, process modeling including assessment of raw materials which can also be used in the framework of services for optimization of the blast furnace process.

As a result, there is an extensive range of services which Paul Wurth is able to offer to their clients.

These services are ranging from process optimization to the support in rare or risky operations and emergency situations. They are of course not limited to the blast furnace, but can also be provided for the areas of sintering, coke-making and raw materials.

Typical services in regard to optimization and assessment are:

- BF process optimization

- $\mathrm{PCl}$ optimization

- Charging optimization

- Operational cost reduction

* Contribuição técnica ao 44 Seminário de Redução de Minério de Ferro e Matérias-primas, $15^{\circ}$ Simpósio Brasileiro de Minério de Ferro e 2o Simpósio Brasileiro de Aglomeração de Minério de Ferro, 15 a 18 de setembro de 2014, Belo Horizonte, MG, Brasil. 
- Production increase

- Campaign life extension with evaluation of hearth erosion

- On-site or abroad training

- Sinter process optimization

- Coke-making process optimization

- Plant assessment

- Raw material assessment

In several other tasks mainly because of their rare occasion Paul Wurth process services provide additional safety and cost reduction by speeding up the process.

- Blow-in and start-up assistance

- Blow-down and quenching

- Salamander tapping

- Chilled hearth recovery

These process services - either via intervention during incidents or preventively by consulting services - increase process efficiency and their results play an important role in the stable and cost effective operation of a blast furnace plant.

The use of such process services is beneficial for blast furnace operators in two ways. On the one hand they indirectly profit from the experiences at other plants and the share of costs. On the other hand these services are affecting operations for which the cost resulting from difficulties which could have been avoided easily outweighs the cost of such services.
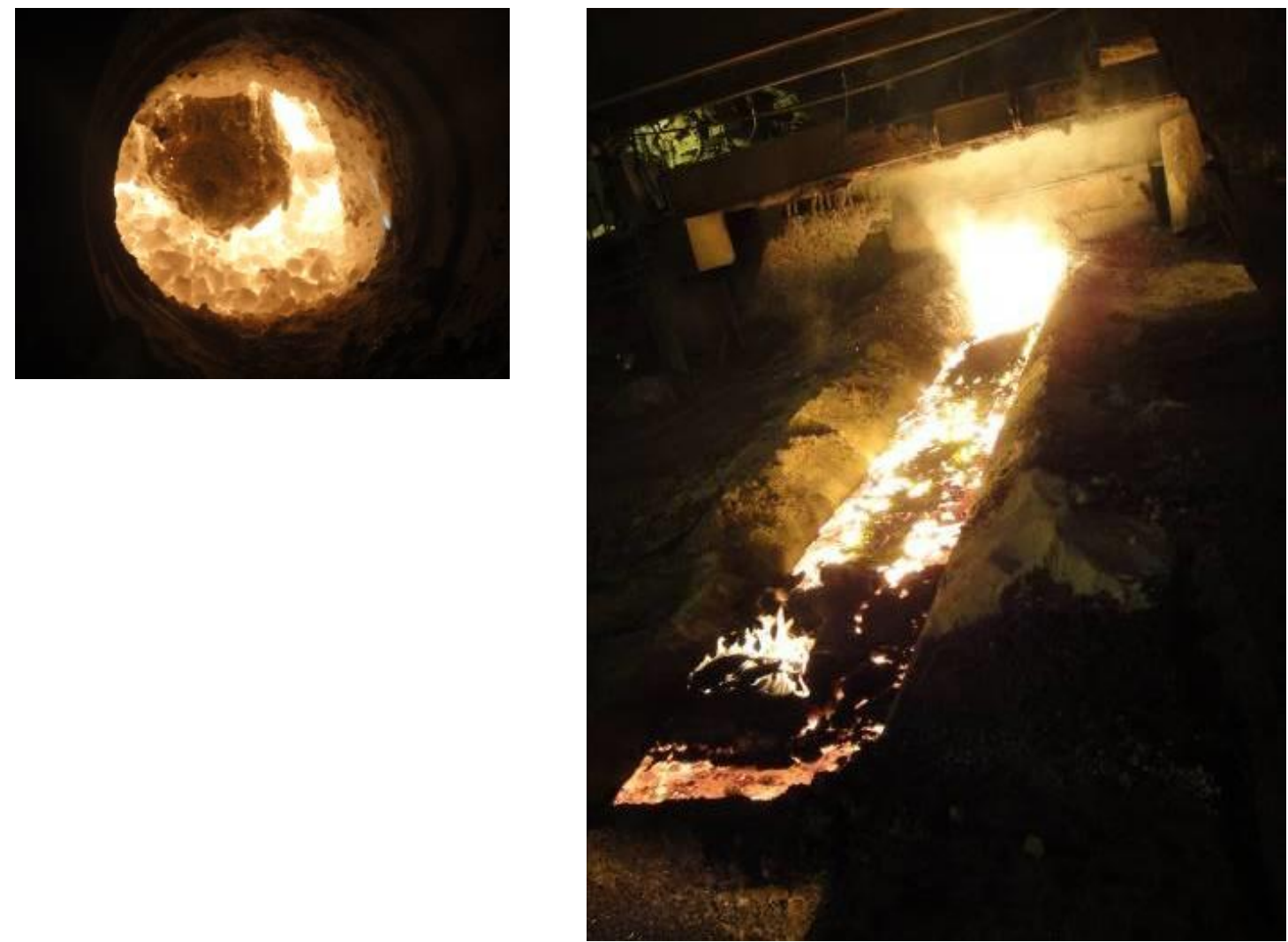

Figure 2. Process service for a chilled BF process - Iran 20111.

One of the most significant examples for this is a blast furnace chilled hearth. The stoppage as a result of the event itself but moreover the drastic decrease of production rate during the recovery from a chilled heart impacts the production costs. The amount of losses and the impact on the supply chain generate a considerable

* Contribuição técnica ao 44 Seminário de Redução de Minério de Ferro e Matérias-primas, 15은 Simpósio Brasileiro de Minério de Ferro e $2^{\circ}$ Simpósio Brasileiro de Aglomeração de Minério de Ferro, 15 a 18 de setembro de 2014, Belo Horizonte, MG, Brasil. 
loss of money. Other immediate consequences can be risks of accidents and negative medium and long term effects in case refractory and cooling systems become affected.

An optimization of the blast furnace process in terms of stability can minimize the risk of a chilled hearth in many cases. Yet, in case of a chilled hearth the target is to recover normal operation conditions in the shortest time possible.

Here, the proper decisions taken make the difference whether the blast furnace can be brought to normal production within 1 week or within 5 weeks.

The potential loss alone highlights the importance of taking all efforts to limit the impact of such incidents on the operation. As with the chilled hearth recovery, all process services are based on crucial and correct assessment of the causes and origins, and the adoption of accurate and quick solutions to minimize losses. Due to costs and production volumes the involved losses grow rapidly in the order of millions of dollars and when impacts in the production chain are calculated these easily exceed tens of millions.

The use of process services during incidents such as prevention or recovery, stability improvement and staff training leads to direct economic benefits for steel companies.

\section{PROCESS SERVICES RELATED TO THE BLAST FURNACE}

The blast furnace can be affected easily by external influences. Lowered production rates can cause unintended consequences for the stability of the blast furnace process with effect on equipment like refractory and cooling systems life-time.

The deterioration of process permeability due to the use of high sinter rates with less quality, fluctuations in coke characteristics and other raw material demand a constant adaptation of the process to the raw material conditions.

Incorrect actions such as reduced peripheral heat flow are among the leading causes of permanent damage to the equipment.

Such instable operation conditions can finally lead to severe damages at tuyeres and cooling elements resulting in an unproductive and undesirable thermal state with the risks of chilling the blast furnace.

Making use of process services brings the possibility to identify best operational setpoints for each situation, to identify and point technological solutions with low investment and ensure adequate prevention and protection. Finally the main target for all of these services is to lower the overall of production costs.

- Feasibility study for productivity increasing

- Analysis of current operation with a focus on energy efficiency and stability

- Parameterization and adjustment for optimal state and evaluation of fuel consumption

- Charging distribution with focus on extension campaign and operational stability and productivity

- Feasibility study for high fuel injection rates and stability with use of multiple fuels

- Campaign extension campaign and impact factors as aspects of liquids drainage in the hearth, stave coolers wear behavior and others;

- Hearth wear control

- Support rebuilds and relines via identifying and indicating appropriate solutions and technologies

- Recovery process from chilled hearth

- Training of technical staff and operational teams

* Contribuição técnica ao 44 Seminário de Redução de Minério de Ferro e Matérias-primas, 15o Simpósio Brasileiro de Minério de Ferro e 2o Simpósio Brasileiro de Aglomeração de Minério de Ferro, 15 a 18 de setembro de 2014, Belo Horizonte, MG, Brasil. 
- Service for short-term problems in the operation or long-term monitoring and continuous improvement

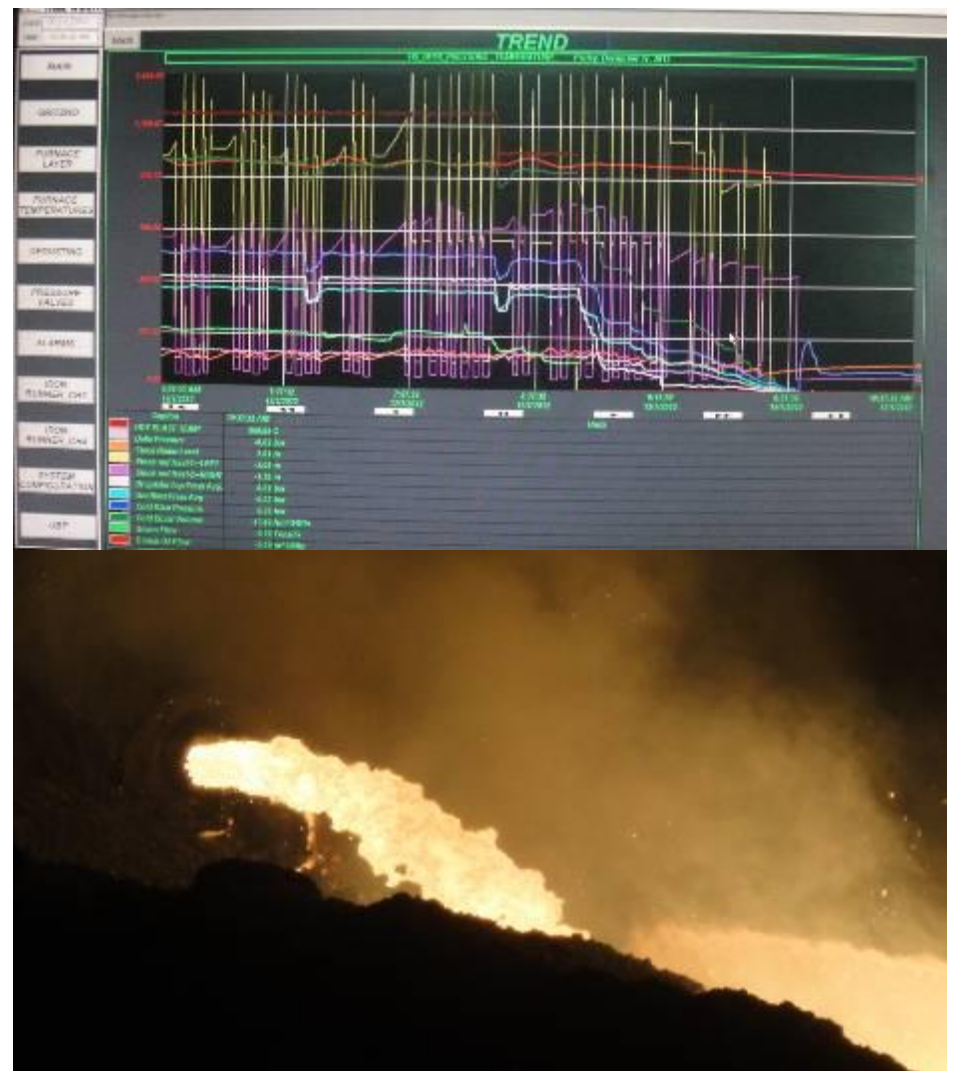

Figure 3. Production increasing assistance - India 2012

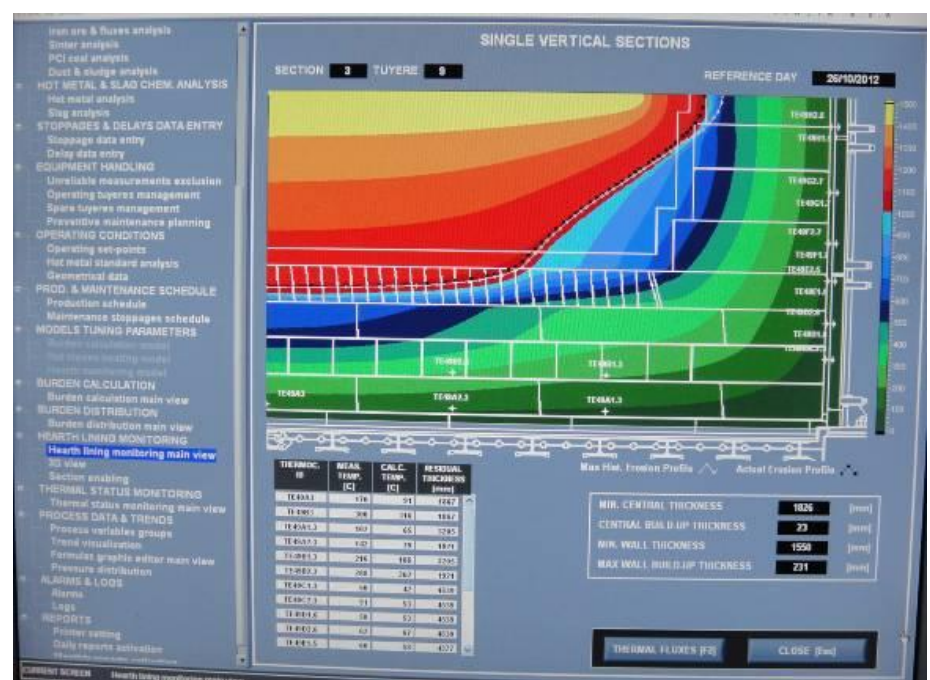

Figure 4. Hearth wear monitoring and investigation.

In the current economic situation it can be seen that blast furnace stoppages became more frequent. Such stoppages are often correlated to difficult and risky operations such as:

- Blow-down and quenching

- Salamander tapping

- Chilled hearth recovery

- Restart of the blast furnace

* Contribuição técnica ao $44^{\circ}$ Seminário de Redução de Minério de Ferro e Matérias-primas, 15은 Simpósio Brasileiro de Minério de Ferro e 2o Simpósio Brasileiro de Aglomeração de Minério de Ferro, 15 a 18 de setembro de 2014, Belo Horizonte, MG, Brasil. 

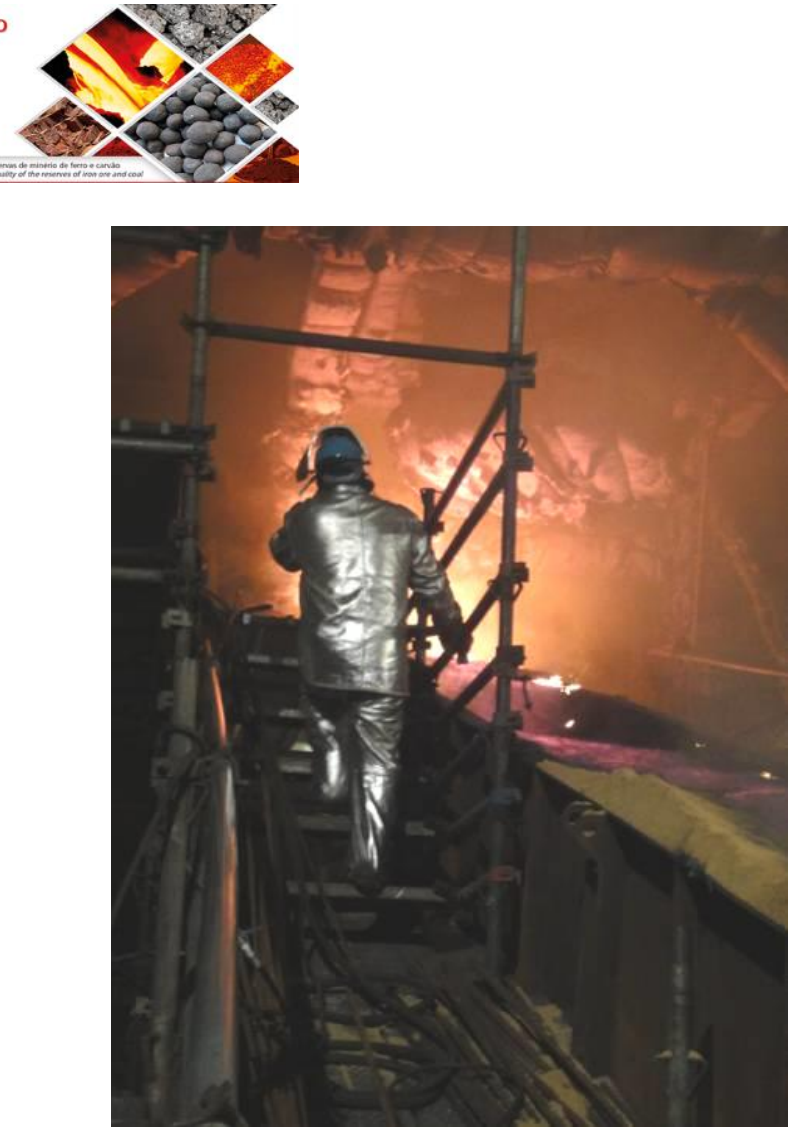

Figure 5. Salamander tapping.

Being supported in these tasks operators gain an increase in safety as a result of a four-eyes-principle and cost saving by time and risk reduction.

\section{PROCESS SERVICES RELATED TO SINTERING}

Worsening in the quality of raw materials sources and increasing environmental constraints make an optimized control of the sintering process mandatory.

Plants face practical constrains such as the need to increase residue consumption for economical reasons and to maintain the same production levels despite decreases in raw material quality.

Optimizing the sintering process makes it necessary to evaluate thoughtfully the sources of raw material. Further a precise understanding of the sintering process is necessary to identify and to determine the optimal operation set-points.

Hereafter some services applicable for sintering process are listed:

- Optimizing the use of alternative waste residues focusing on cost reduction

- Optimizing the use of ultrafine iron ores

- Assessment for raw materials choice (iron ores, solid fuels, fluxes...)

- Identifying points of adjustment for increased productivity and energy saving

- Technical guidance on equipment choice

- Plant audits leading to improved performance and optimized operation

- Improvement of product quality

- Identify and propose corrections to the sources of environmental impacting

- Efficiency increasing

- Global solutions within the integrated steel works

- Training of staff

* Contribuição técnica ao 44 Seminário de Redução de Minério de Ferro e Matérias-primas, 15o Simpósio Brasileiro de Minério de Ferro e 2o Simpósio Brasileiro de Aglomeração de Minério de Ferro, 15 a 18 de setembro de 2014, Belo Horizonte, MG, Brasil. 


\section{PROCESS SERVICES RELATED TO COKE OVEN PLANTS}

Coke ovens are also impacted during crises by the need for battery or individual oven shutdowns to react on decreased production demands. Consequences hereof are loss of income or even refractory damages decreasing the batteries' life-time.

A second factor which further has a direct impact on the blast furnace is the worsening of coking coal quality. The produced lower quality coke causes permeability and productivity decrease and can lead to a premature wear of the blast furnace hearth.

The target in coke making process optimization therefore is to achieve the demanded productivity with the highest coke quality possible.

Among the process services which can be offered for the coke ovens plant are the following:

- Coke ovens performance improvement studies

- Production optimization

- Energy saving

- Ovens and battery campaign extension

- Identify and propose corrections over deviations in thermal profile

\section{PROCESS SERVICES RELATED TO RAW MATERIALS}

Raw materials play a most significant role as their quality directly affects the processes of sintering coke-making and the blast furnace. The efficiency of the plant is therefore directly related to the quality of raw materials and operational deviations are often associated with raw material quality decreases.

Another impact of raw materials comes not from the quality itself but from fluctuations of the latter. Many plants are forced due to the economic situation to accept higher fluctuations in raw material quality than usual. Fast reaction and adaptation of the subsequent processes is necessary to avoid resulting instabilities.

Evaluation of raw materials is a part of the set of services available and knowledge and experience gained over the years of development of engineering processes is made available to the companies making use of process services.

Services applied to raw materials:

- Evaluation of sources of raw materials, mass balance calculations and prediction of future quality according to the particularities of each case

- Prediction of the process behavior according to predicted qualities via analytical calculations

- Determination of optimal set points for chemical, physical and metallurgical qualities

- Conducting quality testing

\section{PAUL WURTH REFERENCES FOR PROCESS SERVICES}

The following non-exclusive list provides several practical examples of the process services conducted by Paul Wurth in the recent past:

- 2011 Iran. Process services were conducted to recovery a chilled operation running on a BF of 2,550 $\mathrm{m}^{3}$ and nominal production of $5,800 \mathrm{tpd}$. In 12 days $65 \%$ of rated capacity was recovered. With the positive results services was prompted by the extension for technical and operational teams training program about identification and recovering of chilled process in blast furnace.

* Contribuição técnica ao $44^{\circ}$ Seminário de Redução de Minério de Ferro e Matérias-primas, $15^{\circ}$ Simpósio Brasileiro de Minério de Ferro e 2o Simpósio Brasileiro de Aglomeração de Minério de Ferro, 15 a 18 de setembro de 2014, Belo Horizonte, MG, Brasil. 
- 2012 India. Process services were successfully performed services for start-up of a BF of $3,600 \mathrm{~m}^{3}$. The breakthrough production curve reached $7,000 \mathrm{tpd}$ in 20 days and 8,000 in 35 days.

- 2012 India. Process service was performed for a BF of $3,400 \mathrm{~m}^{3}$ executing preparation and blow in. Due to plant not foreseen incidents an operation interruption was held after 10 days. Services were extended to recovery the chilled condition, restart and stabilize the process with a maximum production of $40 \%$ of nominal capacity, running successfully.

- 2012 Russia, Assessment of different coal recourses for selection of optimal injection coal

- 2012 Europe, Feasibility study on production increase, raw material preparation \& HBI charging for a major European steel producer

- 2012 India, Chilled hearth recovery and operator training on chilled hearth prevention

- 2012 India, Sinter plant assessment

- 2013 Europe, Blow-down and salamander tapping of $2450 \mathrm{~m}^{3}$ blast furnace under a turnkey package

- 2013 Russia, Metallurgical assistance for the ramp-up of the first pulverized coal injection in Russia at EVRAZ, NTMK works. Total injection rate of 180 $\mathrm{kg} / \mathrm{t}$ was reached in less than 45 days.

- 2013 South Korea. Detailed evaluation of process optimization for campaign life extension

- 2013 Brazil, Blast furnace optimization; Production increase despite worse raw materials

\section{CONCLUSION}

Paul Wurth has the interest and the possibility to serve their customers even in the most demanding tasks. The offered services are varying from optimization studies to complete plant evaluations and include process services to conduct critical operations.

Process Services are a growing practice in the world and the results obtained confirm as an attractive option for the companies, since the costs with such activities represent a small fraction of the amount losses during incidents involving production loss in iron making plants.

\section{REFERÊNCIAS}

1 Alexey Kushnarev, Philipp Bermes, Pierre Mahowald, Georges Stamatakis, Stephan Becker, André Oliveira, Jean-Paul Simões; EVRAZ NTMK PCI start-up; First successful pulverized coal injection start-up in Russia at EVRAZ NTMK, ABM 2013, Brazil.

2 Andre Oliveira, South America Steel Plants Paul Wurth Report, Paul Wurth do Brasil: Belo Horizonte - Brasil, 2013. 